\title{
Assessment of Surface Water Quality of Danube River in Terms of Usual Parameters and Correlation Analyses
}

\author{
ROMANA DRASOVEAN ${ }^{1 *}$, GABRIEL MURARIU1*, GIGI CONSTANTINESCU1', ADRIAN CIRCIUMARU² \\ 'Dunarea de J os University of Galati, Faculty of Sciences and Environment, Department of Chemistry, Physics and Environment, \\ 111 Domneasca Str., 800008, Galati, Romania \\ 2Dunarea de J os University of Galati, Cross-Border Faculty, 111 Domneasca Str., 800008, Galati, Romania
}

In order to determine the water quality of Danube River, in the Galati area, the Water Quality Index was calculated. Water Quality Index is a useful number of overall qualities of water. Galati is a Danube port city located in south-eastern of Romania. Samples were taken from 9 places along the Danube starting with the place where the Siret flows into the Danube to the Profiland Steel Plant. Profiland Steel is a company in Galai whose main activities are: sheet and zinc strips; treatment and coating of metals. The monitoring period was one year, from November 2016 to December 2017. Every month, thirty physical - chemical parameters were investigated. In this study the assessment of surface water quality was determined on the basis of various indicators such as: potassium and calcium ions, nitrites, nitrates, total nitrogen, ammonium, chlorides, total phosphorus, sulphates, cadmium, chrome, copper, lead, iron, zinc, density, dissolved oxygen, chemical oxygen demand (CCO-Cr), biochemical oxygen demand (CBO5), electrical conductivity, the density of the conductivity, resistivity, $\mathrm{pH}$, salinity, total dissolved solids. The water quality index (WQI) has been calculated by using Weighted Arithmetic Water Quality Index Method. Two types of correlations were developed: Pearson correlation matrix and Spearman correlation.

Keywords: Weighted Arithmetic Method, Water Quality Index, Pearson correlation matrix, Spearman correlation

The quality of water is determined by the biological, chemical and physical parameters of water. According to the World Health Organization (WHO), water quality expresses the suitability of water to sustain various uses or processes. Any particular use requires some requirements regarding the physical-chemical parameters of water [1].

Water quality indices and water indicators have been developed since 1848 [2]. The water quality indices are mathematical tools, which are used to simplify the information about water quality parameters. By using these mathematical tools, the water quality is represented by a single number $[3,4]$.

A large number of methods for determining water quality indices have developed around the world [5]. The main differences between these methods are the way of statistical incorporation (the way in which their sub-index is calculated) and meaning of parameter values [5]. Subindices can be linear, nonlinear, segmented linear and segmented nonlinear [6].

In order to determine the water quality of Danube River, in the Galati area, the Water Quality Index was calculated and the Karl Pearson correlation matrix and Spearman correlation for water samples was developed.

In this study, the water quality index (WQI) has been calculated by using Weighted Arithmetic Water Quality Index Method. This method was proposed by Horton in 1965 and developed by Brown et al. in 1970 and then, by Cude, in 2001 [5].

The following formula was used to determine the quality index WQI according to $[3,4,7]$ :

$$
W Q I=\frac{\sum q_{n} W_{n}}{\sum W_{n}}
$$

here, $q_{n}$ is the quality rating of the $n^{\text {th }}$ parameter of water quality

$$
q_{n}=\frac{V_{n}-V_{i a}}{s_{n}-V_{i a}} \times 100
$$

$W_{n}$ is the unit weight of $n^{\text {th }}$ water quality parameter; $V_{n}$ is the estimated value of $n^{\text {th }}$ water quality parameter at ${ }^{n}$ given sample; $V_{\text {id }}$ is the Ideal value for the $n^{\text {th }}$ parameter in pure water; $S$ is the standard permissible value of the $n$th parameter; $K$ is a proportionality constant.

$$
W_{n}=\frac{K}{S_{n}}
$$

The Water Quality Status is Excellent if the W QI Level is between 0 and 25, Good for 26-50, Poor for 51-75, Very Poor for 76-100 and Unsuitable for drinking when the WQI Level is greater than $100[8,9]$.

Two types of correlation coefficients were also calculated in order to study the association between two parameters and the direction of their relationship. The linear correlation was evaluated using Pearson correlation coefficient, $r$. Pearson coefficient is a statistical measure of the strength of a linear relationship between two parameters. Pearson coefficient, $r$, and can be calculated using the formula:

$$
r=\frac{S_{x y}}{S_{x} S_{y}}
$$

where $S_{x y}$ is the covariance and $S_{x^{\prime}} S_{y}$ are the standard deviation of parameters $x$ and $y$.

The second analysis method used for our parameters was based on Spearman correlation method is a nonparametric test more appropriate to use when the relationship between the variables is not linear. The same approach but for other purposes had been used in [10-13] .

\footnotetext{
* email: rdrasov@ugal.ro; gabriel.murariu@ugal.ro
} 


\section{Experimental part}

\section{The study area}

Water samples were collected from nine Danube sites between November 2016 and December 2017. The water sampling points were disposed along the Danube river bank from Galati. Galati is the Capital City of Galati County, in the east of Romania. Galati, the 8th most populous city in Romania, is a port city on the Danube and an important economic centre.

The water samples were coded as follows:

-D1, D2, D3 - are samples taken from Danube river, next to the ferry-boat station and the pipelines coming from industrial and commercial agencies in the area;

-D4, D5, D6 - are samples taken next to a chain of restaurants and hotels;

$-D 7, D 8, D 9$ - are samples which were taken from the area of Intfor SA Rolling Mill.

During the first part of monitoring period it had been observed that the measured values are the same for D1, D2 and D3 points and also for the other two groups of three points. In order to simplify the presentation we choose to expose only the dates for D1, D4 and D7 points (fig. 1).

\section{Water anlyses}

All the 26 indicators for all water samples were investigated, each month during the monitoring period. The measured parameters were: sodium, potassium and calcium ions, nitrites, nitrates, total nitrogen, ammonium, chlorides, total phosphorus, sulphates, sulphides and hydrogen sulphide, solvent extractable substances, anionic surface agents, cadmium, chrome, copper, lead, iron, zinc, dissolved oxygen, chemical oxygen demand (CCO-Cr), biochemical oxygen demand (CBO5), electrical conductivity, resistivity, $\mathrm{pH}$, salinity and total dissolved solids.

All water samples were analyzed according to the Romanian standard procedures. Water Standards permissible values used in this study were taken from Romanian Legislation, Order 161/2006. The standards for third category surface waters were used. These surface waters are moderately polluted due to human activities [13].

\section{Results and discussions}

During the studied period, $\mathrm{pH}$ values of all collected samples ranged between 5.36 and 6.59. The $\mathrm{pH}$ of water determines the solubility and biological availability [14]. Metals tend to be more toxic at lower $p \mathrm{H}$ because they are more soluble. The studied metals were: cadmium, chromium, copper, lead, iron and zinc. For the studied metals an important Spearman statistical correlation was obtained (table 1 ) with the two-tailed value of $P=0$. The

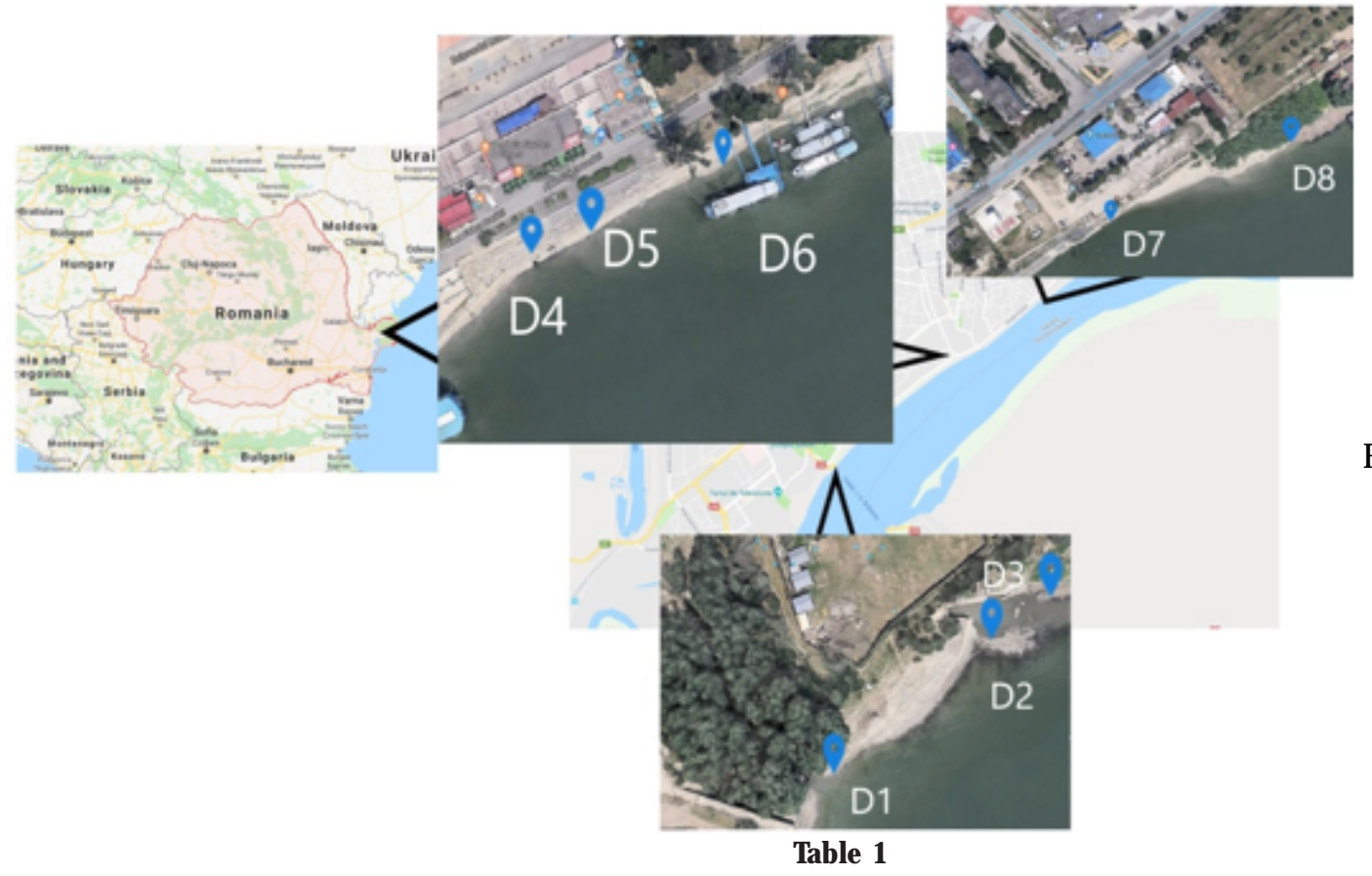

Fig.1. Sampling points

SPEARMAN CORRELATION BETWEEN $p H$ AND METALS

\begin{tabular}{|c|c|c|c|}
\hline Correlated parameters & $\mathbf{r s}^{*}$ & $\mathrm{P}^{* *}$ & Statistical Association \\
\hline $\mathrm{pH}-L$ ead & -0.7158 & 0 & $\begin{array}{c}\text { the association between the two variables would be considered } \\
\text { statistically significant }\end{array}$ \\
\hline $\mathrm{pH}-\mathrm{Zn}$ & -0.7864 & 0 & $\begin{array}{c}\text { the association between the two variables would be considered } \\
\text { statistically significant }\end{array}$ \\
\hline $\mathrm{pH}-$ Iron & -0.68692 & 0 & $\begin{array}{c}\text { the association between the two variables would be considered } \\
\text { statistically significant }\end{array}$ \\
\hline $\mathrm{pH}-\mathrm{Cu}$ & -0.42123 & 0 & $\begin{array}{c}\text { the association between the two variables would be considered } \\
\text { statistically significant }\end{array}$ \\
\hline pH-Cr & -0.35712 & 0 & $\begin{array}{c}\text { the association between the two variables would be considered } \\
\text { statistically significant }\end{array}$ \\
\hline
\end{tabular}


Spearman correlation was negative which means there was a tendency for high metals variable scores with smaller $\mathrm{pH}$ variables scores.

During the studied period, $\mathrm{pH}$ values of all collected samples ranged between 5.36 and 6.59 . The $\mathrm{pH}$ of water determines the solubility and biological availability [14] (fig.2). Metals tend to be more toxic at lower pH because they are more soluble. The studied metals were: cadmium, chromium, copper, lead, iron and zinc. For the studied metals an important Spearman statistical correlation was obtained (table 1) with the two-tailed value of $\mathrm{P}=0$. The Spearman correlation was negative which means there was a tendency for high metals variable scores with smaller $\mathrm{pH}$ variables scores (fig. 2.a).

During monitoring, the concentrations of these metals have had the same trend of variation Between November
2016 and June 2017, all metals, with the exception of cadmium, had exceeded the limit permitted by Romanian law. The highest increases in these concentrations were recorded in December, April and June (table 3). Concentrations of sodium and potassium ions were below the limit for all samples throughout the monitoring period.

Chemical oxygen demand ( $\mathrm{CCO}-\mathrm{Cr}$ ) values of all samples ranged from 110 to $125 \mathrm{mg} / \mathrm{L}$, exceeding the limit value of $50 \mathrm{mg} / \mathrm{L}$ [14]. Biochemical oxygen demand (CBO5) has recorded values between 22-125 mg/L compared to the limit value of $7 \mathrm{mg} / \mathrm{L}$. High values of CCO$\mathrm{Cr}$ and $\mathrm{CBO} 5$ indicates the presence of the organic substances in water. In all the samples collected during the monitoring were found large amounts of solvent extractable substances and anionic surface agents (fig.3).
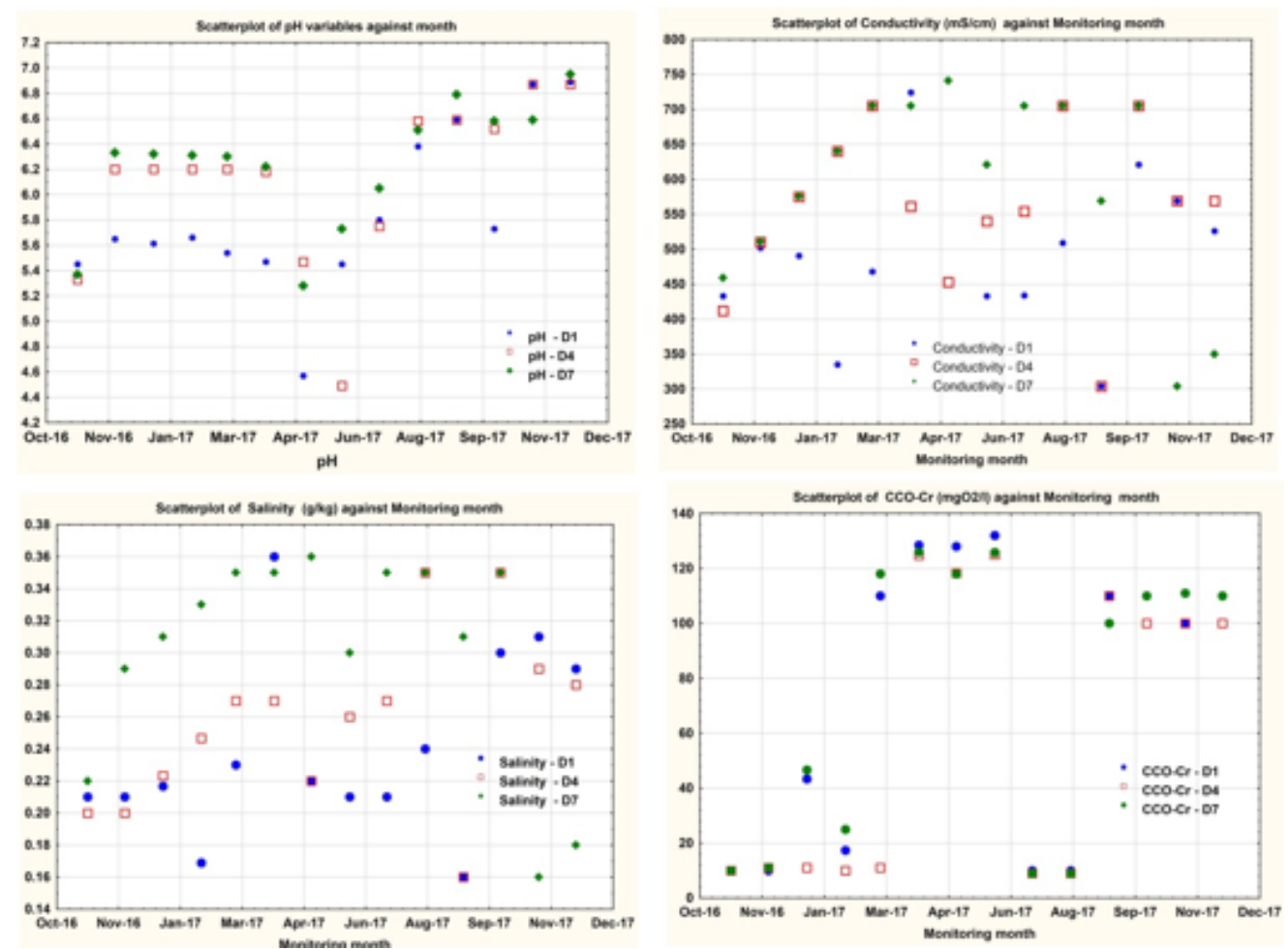

Bou Plot of pell grouped by scation
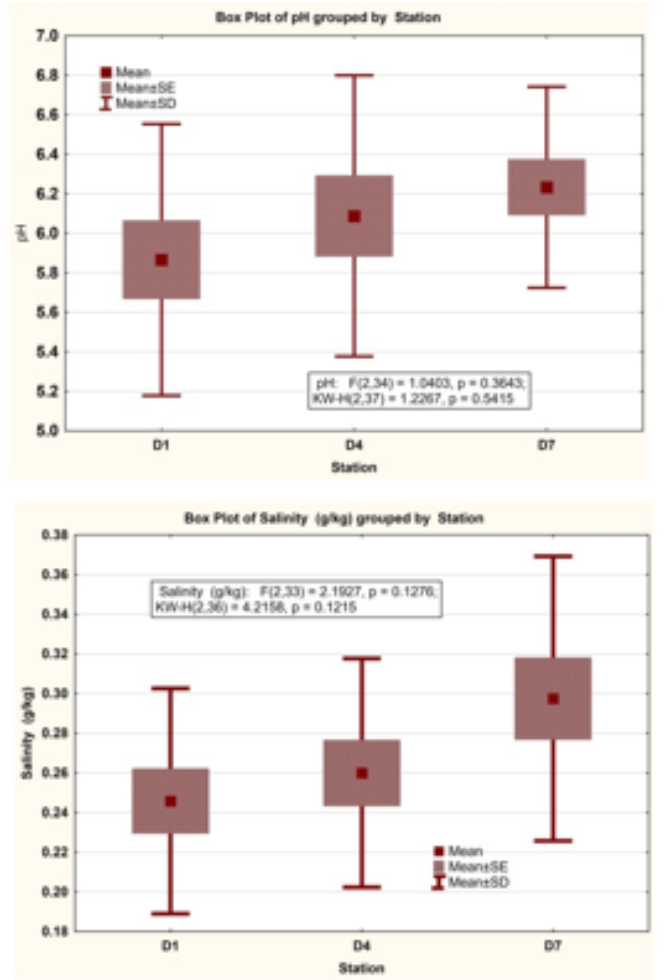
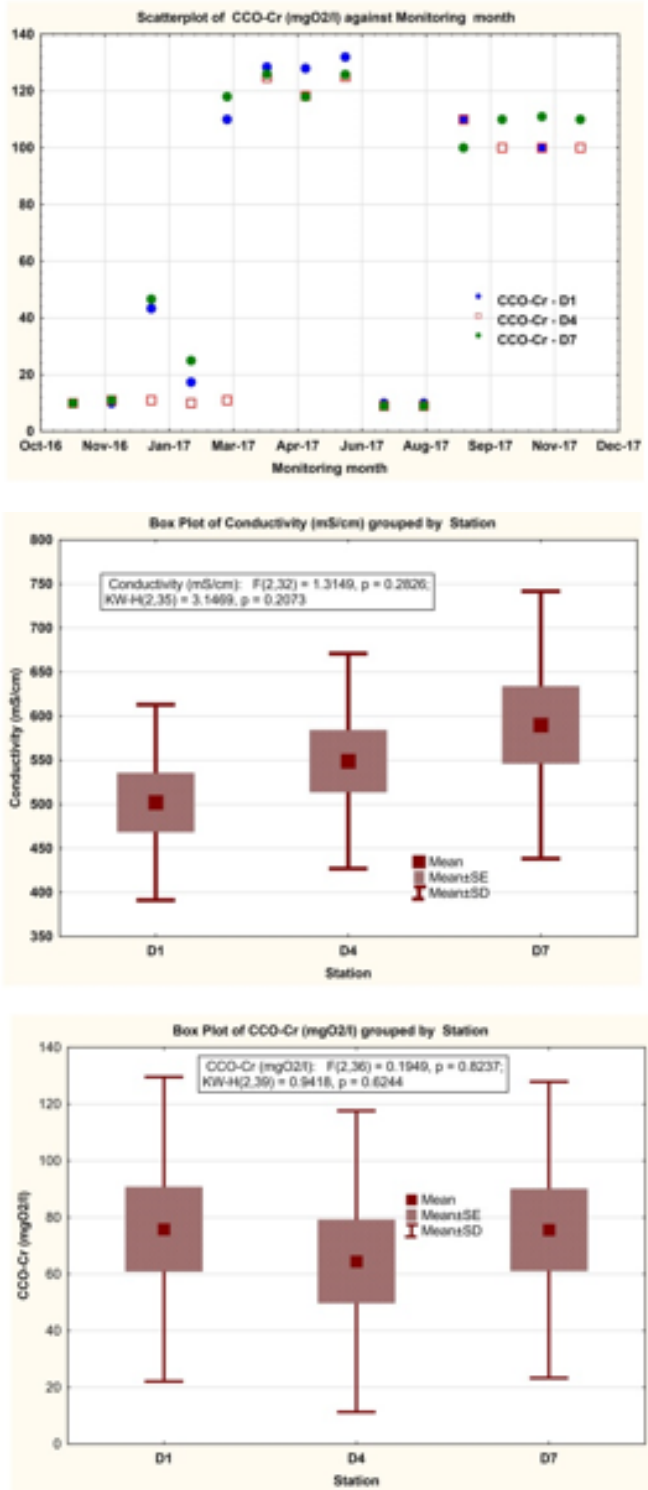

Fig. 2. Monthly evolution for chemical parameters $\mathrm{pH}$, conductivity, salinity and $\mathrm{CCO}-\mathrm{Cr}$
Fig. 2a. Box-plot representation to investigate the values recorded in different monitoring points for $\mathrm{pH}$, conductivity, salinity and $\mathrm{CCO}-\mathrm{Cr}$ 


\begin{tabular}{|c|c|c|c|}
\hline Correlated parameters & $\mathbf{r}_{S}$ & $\mathbf{p}$ & Statistical Association \\
\hline pH-Sulphide and hydrogen sulphide & -0.32672 & 0 & \multirow{4}{*}{$\begin{array}{l}\text { the association between the two variables } \\
\text { would be considered statistically significant }\end{array}$} \\
\hline CBO5-Solvent extractable substances & 0.3818 & 0 & \\
\hline CBO5-Anionic surface agent & 0.39961 & 0 & \\
\hline CCOCr-Solvent extractable substances & 0.136046 & 0.01879 & \\
\hline $\mathrm{CCOCr}$-Anionic surface agent & -0.03934 & 0.49875 & $\begin{array}{l}\text { the association between the two variables } \\
\text { would not be considered statistically } \\
\text { significant. }\end{array}$ \\
\hline CBO5-DO & 0.45193 & 0 & $\begin{array}{l}\text { the association between the two variables } \\
\text { would be considered statistically significant }\end{array}$ \\
\hline TDS-Solvent extractable substances & -0.083119 & 0.15234 & $\begin{array}{l}\text { the association between the two variables } \\
\text { would be considered statistically weak }\end{array}$ \\
\hline TDS-Total Phosphorus & -0.13473 & 0.01999 & \multirow{11}{*}{$\begin{array}{l}\text { the association between the two variables } \\
\text { would be considered statistically significant }\end{array}$} \\
\hline DO-Nitrites & -0.3609 & 0 & \\
\hline DO-Nitrates & -0.43492 & 0 & \\
\hline DO-Total Phosphorus & -0.30168 & 0 & \\
\hline DO-Sulphates & -0.30134 & 0 & \\
\hline Sulphates-Total Phosphorus & 0.749115 & 0 & \\
\hline Nitrates-Nitrites & 0.89753 & 0 & \\
\hline Sulphates-Nitrites & 0.582571 & 0 & \\
\hline Sulphates-Nitrates & 0.6869 & 0 & \\
\hline Total Phosphorus-Nitrites & 0.634196 & 0 & \\
\hline Total Phosphorus-Nitrates & 0.695556 & 0 & \\
\hline
\end{tabular}

Table 2

SPEARMAN CORRELATION BETWEEN WATER PARAMETERS

Table 3

RANGE OF OBTAINED VALUES FOR SOME INDICATORS

\begin{tabular}{|c|c|c|c|}
\hline Parameter & Standard $[12]$ & Period & $\begin{array}{c}\text { Range of } \\
\text { obtained values }\end{array}$ \\
\hline $\mathrm{pH}$ & $6.5-8.5$ & \multirow{5}{*}{ throughout the monitoring period } & $5.45-6.59$ \\
\hline $\mathrm{CCO}-\mathrm{Cr}\left(\mathrm{mgO}_{2} / \mathrm{l}\right)$ & 50 & & $110-125$ \\
\hline $\mathrm{CBO} 5\left(\mathrm{mgO}_{2} / \mathrm{l}\right)$ & 7 & & $22-112$ \\
\hline $\begin{array}{c}\text { Index of total dissolved solids, } \\
\text { TDS (ppm) }\end{array}$ & 200 & & $217-365$ \\
\hline Dissolved oxygen DO (mg/l) & 5 & & $5.57-7.24$ \\
\hline \multirow{2}{*}{ Chlorides (mg/) } & \multirow{2}{*}{250} & November 2016-June 2017 & $300-500$ \\
\hline & & July-December 2017 & $0.001-18$ \\
\hline \multirow{2}{*}{ Nitrites (mg/l) } & \multirow{2}{*}{0.06} & November 2016-June 2017 & $2.1-3.8$ \\
\hline & & July-December 2017 & $0.001-0.01$ \\
\hline \multirow{2}{*}{ Nitrates (mg/l) } & \multirow{2}{*}{5.6} & November 2016-June 2017 & $16-41$ \\
\hline & & July-December 2017 & $0.001-0.2$ \\
\hline
\end{tabular}


Table 3 CONTINUATED

\begin{tabular}{|c|c|c|c|}
\hline \multirow{2}{*}{ Ammonium (mgN/l) } & \multirow{2}{*}{1.2} & November 2016-June 2017 & $1.3-3.8$ \\
\hline & & July-December 2017 & $0.01-0.02$ \\
\hline \multirow{2}{*}{ Total nitrogen $(\mathrm{mg} / \mathrm{l})$} & \multirow{2}{*}{12} & November 2016-June 2017 & $15-20$ \\
\hline & & July-December 2017 & $0.01-1.1$ \\
\hline Sulfates (mg/l) & 250 & throughout the monitoring period & $0.08-1.5$ \\
\hline \multirow{2}{*}{ Lead (mg/l) } & \multirow{2}{*}{0.025} & November 2016-April 2017 & 0.05 \\
\hline & & April-December 2017 & $0.001-0.04$ \\
\hline Cadmium (mg/l) & 2 & throughout the monitoring period & $0.001-0.003$ \\
\hline \multirow[b]{2}{*}{ Total Phosphorus (mg/l) } & \multirow[b]{2}{*}{0.75} & $\begin{array}{c}\text { November 2016-March 2017, August } \\
2017 \text {, September } 2017\end{array}$ & $1-2.1$ \\
\hline & & $\begin{array}{c}\text { April- June 2017, } \\
\text { October- December } 2017\end{array}$ & $0.001-0.3$ \\
\hline \multirow{2}{*}{$\operatorname{Iron}(\mathrm{mg} / \mathrm{l})$} & \multirow[b]{2}{*}{1} & April- June 2017 & $3-4.9$ \\
\hline & & $\begin{array}{l}\text { November 2016-March 2017, July- } \\
\text { December } 2017\end{array}$ & $0.001-0.8$ \\
\hline Zinc (mg/l) & 0.5 & April-May 2017 & $0.8-1.2$ \\
\hline \multirow{2}{*}{ Copper (mg/l) } & \multirow{2}{*}{0.05} & November 2016-June 2017 & $0.1-0.5$ \\
\hline & & July-December 2017 & 0.001 \\
\hline
\end{tabular}

Table 4

KARL PEARSON CORRELATION MATRIX FOR WATER SAMPLES

\begin{tabular}{|c|c|c|c|c|c|c|c|c|c|c|c|c|c|c|c|}
\hline Panmecen & $\mathrm{pH}$ & $\begin{array}{c}\mathrm{EC} \\
(\mu \mathrm{B} c m)\end{array}$ & $\begin{array}{l}\text { TDS } \\
(\text { (ppm) })\end{array}$ & $\underset{(\mathrm{mg} 1)}{\mathrm{DO}}$ & $\begin{array}{l}\text { CoOCr: } \\
(\mathrm{mg} \mathrm{Cat})\end{array}$ & Sulinity & $\begin{array}{l}\text { Chilrids } \\
\text { (mgi) }\end{array}$ & $\begin{array}{l}\text { Natites } \\
\text { (mg1) }\end{array}$ & $\begin{array}{l}\text { Nirsa } \\
(\mathrm{mg} 1)\end{array}$ & $\begin{array}{l}\text { Anmmenisen: } \\
\text { (mgNi) }\end{array}$ & $\begin{array}{c}\text { Total } \\
\text { atrogen } \\
\text { (mal) }\end{array}$ & $\begin{array}{l}\text { Solphxes } \\
\text { (mg1) }\end{array}$ & $\begin{array}{c}\text { Total } \\
\text { Phosphoru } \\
\text { simz/ll }\end{array}$ & $\begin{array}{c}\text { Solvent } \\
\text { extractable } \\
\text { sulatancse } \\
\text { (mal) }\end{array}$ & $\begin{array}{l}\text { Anlonc } \\
\text { Dutace } \\
\text { agents } \\
\text { (mz/1) }\end{array}$ \\
\hline $\mathrm{aH}$ & 1 & & & & & & & & & & & & & & \\
\hline $\mathrm{EC}(-\mathrm{B} / \mathrm{am})$ & -0.0905 & 1 & & & & & & & & & & & & & \\
\hline $\operatorname{TDS}(\mathrm{ppm})$ & 0.0435 & 0.9174 & 1 & & & & & & & & & & & & \\
\hline DO (mgl) & 0.48 & 0.3916 & -0.3792 & 1 & & & & & & & & & & & \\
\hline $000 \cdot \mathrm{Cr}(\mathrm{mg} \mathrm{O}=1)$ & -00093 & 0.0721 & 0.0198 & 0.3426 & 1 & & & & & & & & & & \\
\hline 3alinity & 0.1648 & 0.87 & 0.9394 & -0.2272 & Q. 1432 & 1 & & & & & & & & & \\
\hline Cabrideu(mal) & -0.578 & 0.0974 & 0.0479 & -0.4975 & 0,024 & -0.0732 & 1 & & & & & & & & \\
\hline Nexte $(\operatorname{mg} 1)$ & $-0 \subseteq 66$ & 0.0078 & -0.075 & -0.4091 & $0 \cos 51$ & -0.1783 & 0.8757 & 1 & & & & & & & \\
\hline Nexrasimg 1) & -0.6796 & 0.0344 & -0.0573 & -0.4699 & -0.0371 & -0.1992 & 0.994 & 0.8799 & 1 & & & & & & \\
\hline Ammonivm (m) & 0.1585 & 0.1701 & 0.1954 & -0.207 & 0.3134 & 0.1696 & 0.4042 & 0.3221 & 0.2549 & 1 & & & & & \\
\hline Totd aitogen(mg) & -0.4326 & 0.0231 & -0.0123 & -0.4545 & -0.325 & -0.1599 & 0 2า76 & 0.6209 & 0.7679 & 0.1247 & 1 & & & & \\
\hline Sulpava (mgi) & -0.1328 & 0.0398 & 0.0558 & -0.0935 & -0.1958 & 0.0384 & 0.426 & 0.2858 & 0.3488 & -0.0445 & 0.5200 & 1 & & & \\
\hline Total Phosphona/ma/l & -0.2926 & -00068 & -0.049 & 0.438 & -0.6341 & -0.2079 & 0.4539 & 0.3434 & 0.4457 & 0.2585 & 0.7304 & 0.3851 & 1 & & \\
\hline $\begin{array}{l}\text { Solvert extradtabe } \\
\text { bustancs (mal) }\end{array}$ & -0.3348 & -0.0443 & -0.1365 & 0.1711 & -0.0729 & -0.2859 & 0.4137 & 0.4879 & 0.4867 & 0.040 & 0.3387 & 0.1202 & Q. 1181 & 1 & \\
\hline Anionc asteceaserts/mz/l & -0.4314 & 0.2665 & 0.0923 & 0.2055 & Q. 1831 & 0.0432 & 0.3518 & 0.3624 & 0.4423 & 0.0446 & 0.2500 & 0.1683 & -0.1009 & 0.5452 & 1 \\
\hline
\end{tabular}

Since the ANOVA analysis returned $p$ values in the interval $0.22<p<0.9$ it might be noticed the fact that these parameters spatial variation is insignificant from one monitoring point to another (fig. 3a). Both CCO-Cr and CBO5 bear significant positive Spearman correlation between solvent extractable substances and anionic surface agents (table 2).

ANOVA analysis showed that the $p$ varies between $0.7<p<0.9$ for the $\mathrm{NO}_{2}, \mathrm{NO}_{3}, \mathrm{NH}_{4}$ and $\mathrm{N}_{\text {tom }}$ measurements for one year and a half, so the annual variations of these radicals (fig. 4) proved to be insignificant from the spatial distribution point of view (from a monitoring point to another the differences are small) -(fig. 4.a).
The annual variation of the $\mathrm{Pb}, \mathrm{Cd}$, Fe and $\mathrm{Zn}$ measured concentrations are shown in figure 5 . The spatial variation for these parameters, from one monitoring point to another, seems to be insignificant (fig. $5 a$ ) since the ANOVA analysis presented values for the $p$ coefficient $0.48<p<0.98$.

The annual variations of the $\mathrm{SO}_{4}$ and $\mathrm{P}_{\text {total }}$ measured concentrations are shown in figure 6 . But these variations are insignificant while the ANOVA analysis, once again, returns a value of $p$ coefficient over 0.7 (fig. 6.a).

The analysis revealed that along the left side of the Danube River there are not significant differences between water quality parameters. 

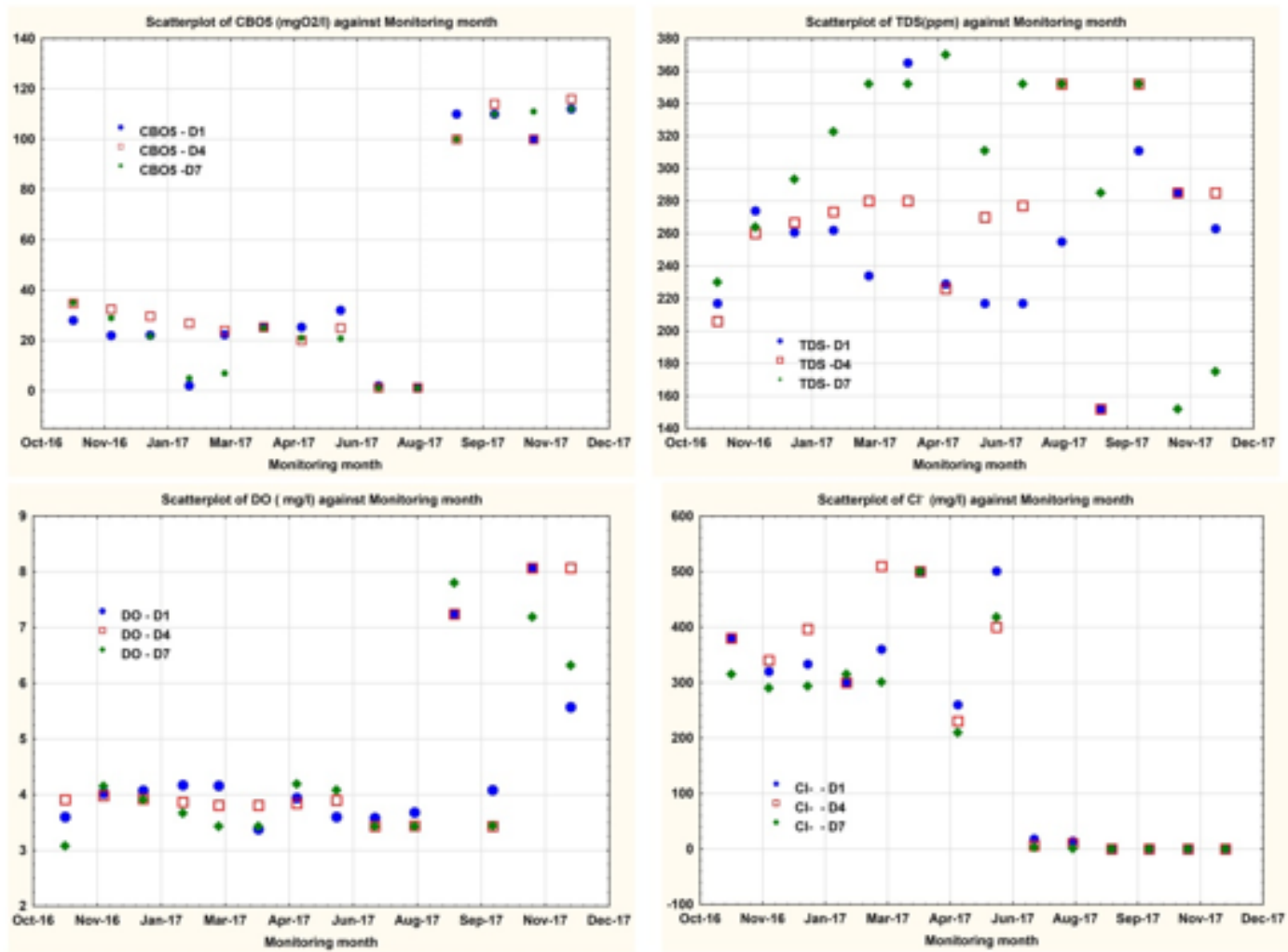

Fig.3. Monthly evolution for CBO5, TDS, OD and Cl-.
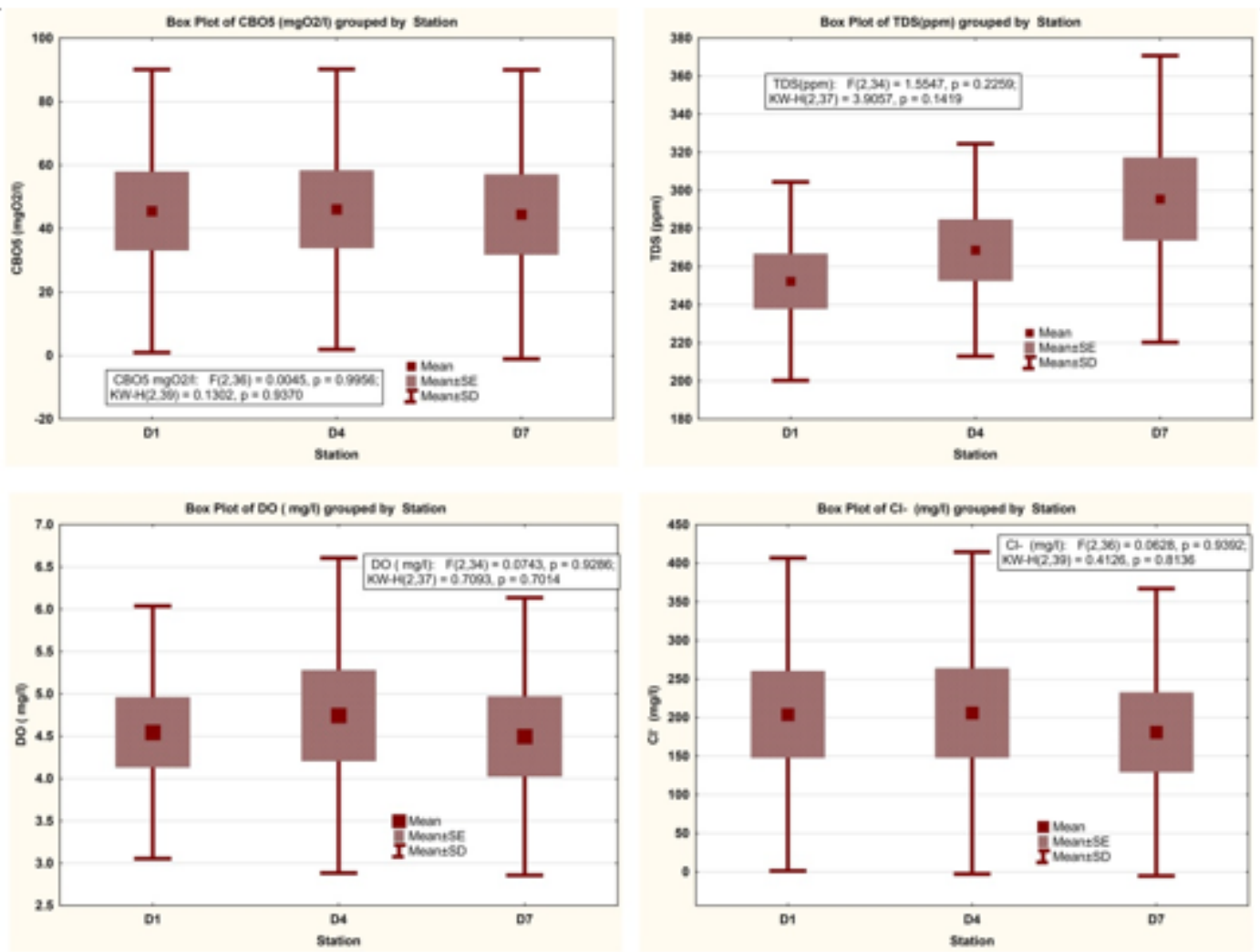

Fig.3a. Box-plot representation to investigate the values recorded in different monitored points for CBO5, TDS, OD and Cl- 

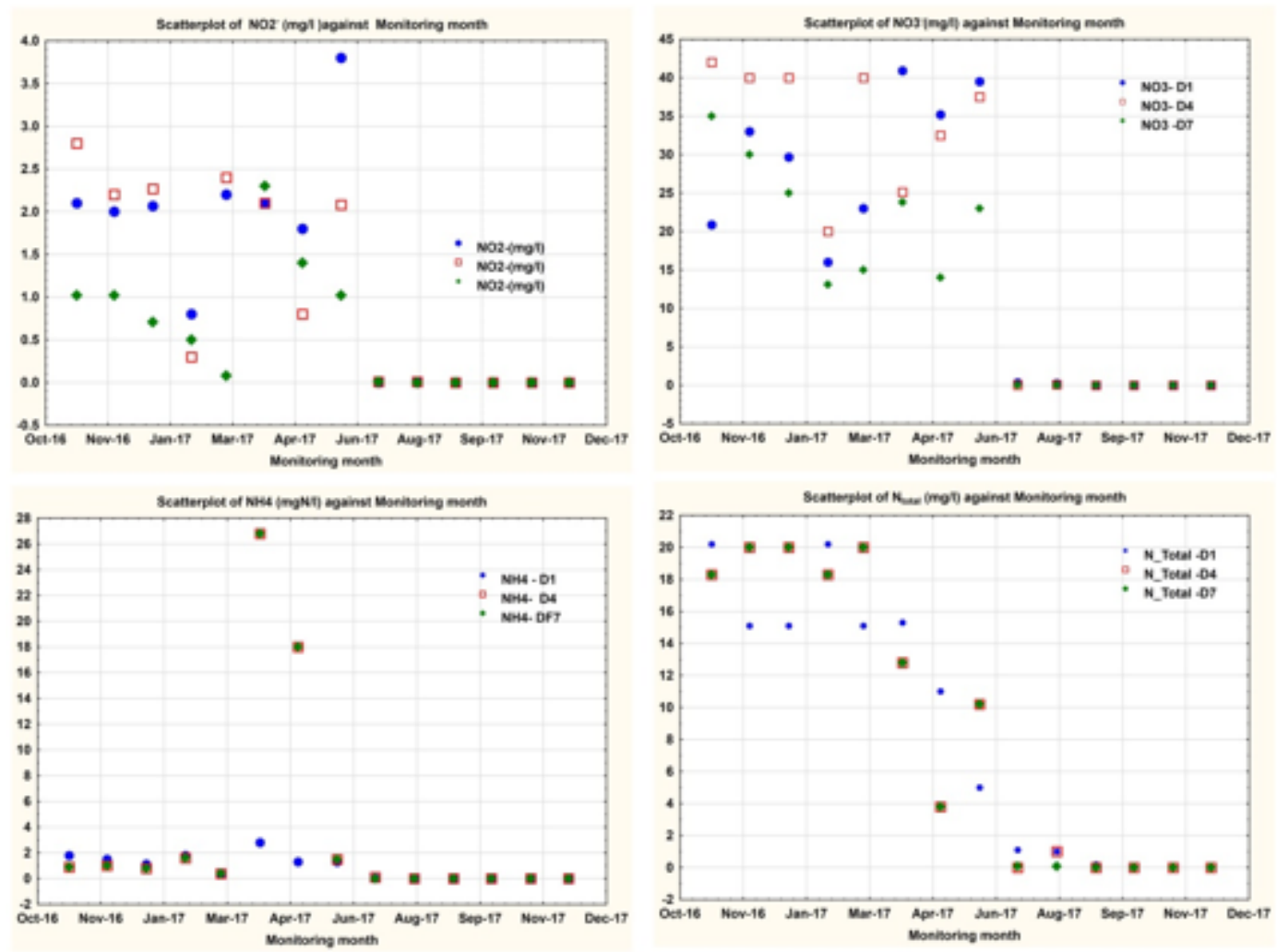

Fig.4. Monthly evolution for $\mathrm{NO}_{2}, \mathrm{NO}_{3}, \mathrm{NH}_{4}$ and $\mathrm{N}_{\text {total }}$
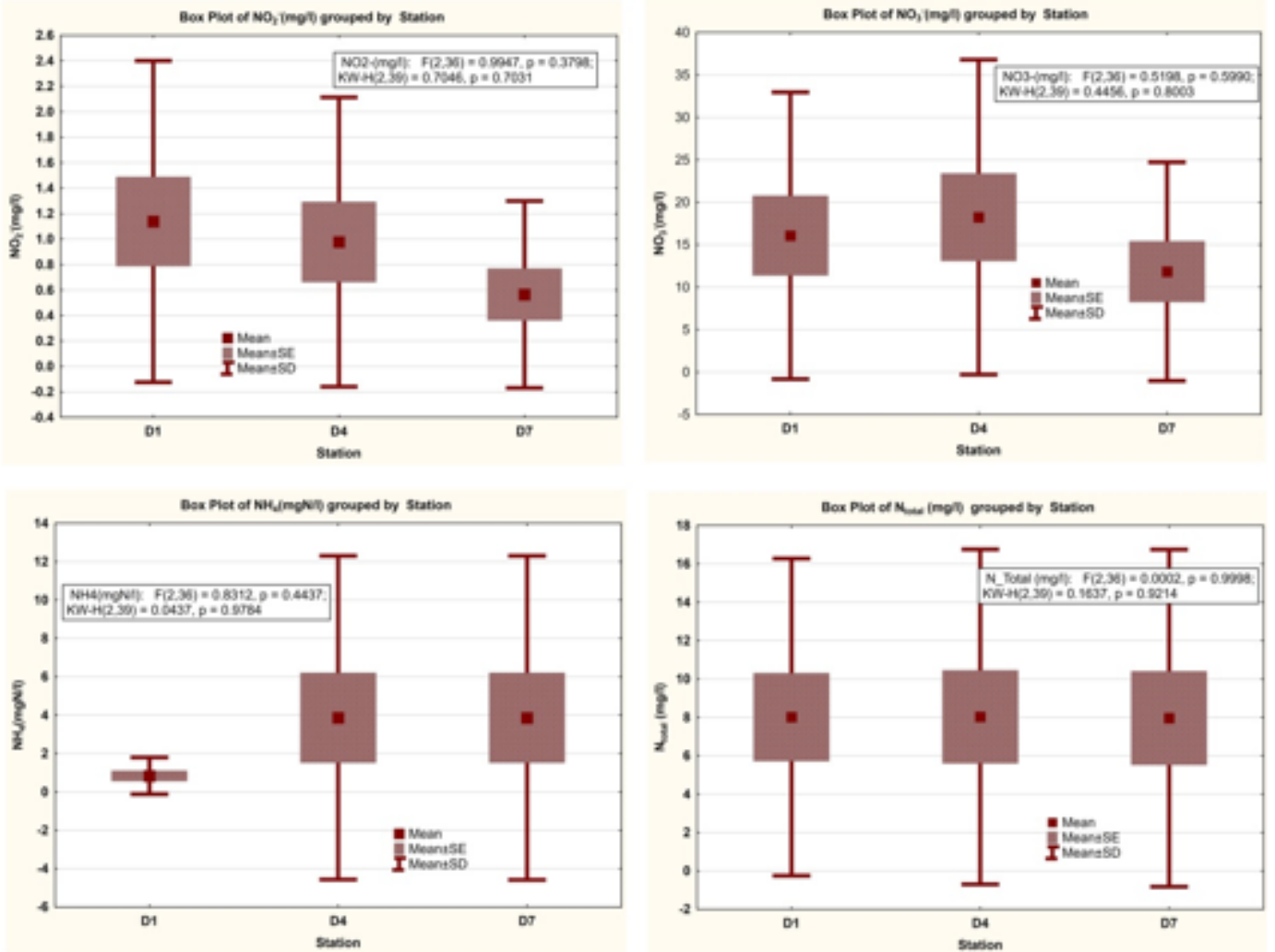

Fig.4a. Box-plot representation to investigate the values recorded in different monitoring points for $\mathrm{NO}_{2}, \mathrm{NO}_{3}, \mathrm{NH}_{4}$ and $\mathrm{N}$ total 

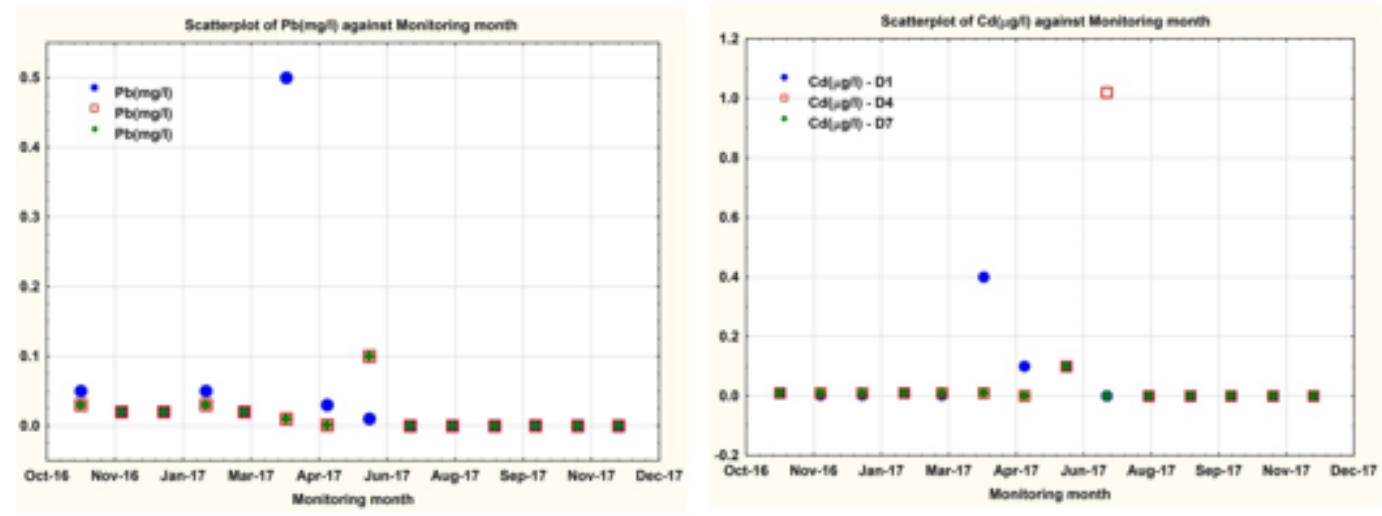

Fig.5. Monthly evolution for $\mathrm{Pd}, \mathrm{Cd}, \mathrm{Fe}$ and $\mathrm{Zn}$
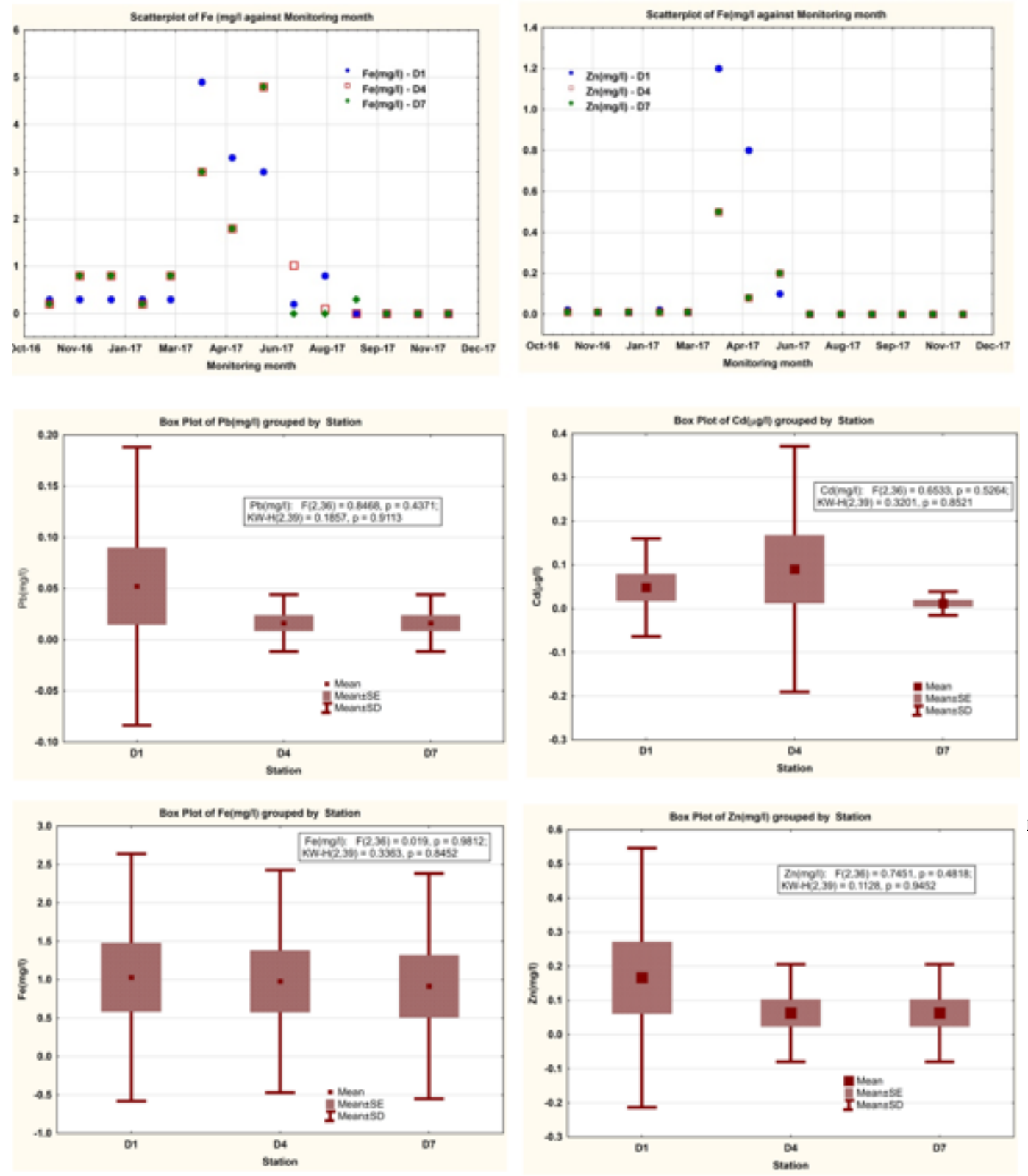

Fig.5a. Box-plot representation to investigate the values recorded in different monitoring points phosphorus $\mathrm{Pb}, \mathrm{Cd}$, Fe and $\mathrm{Zn}$
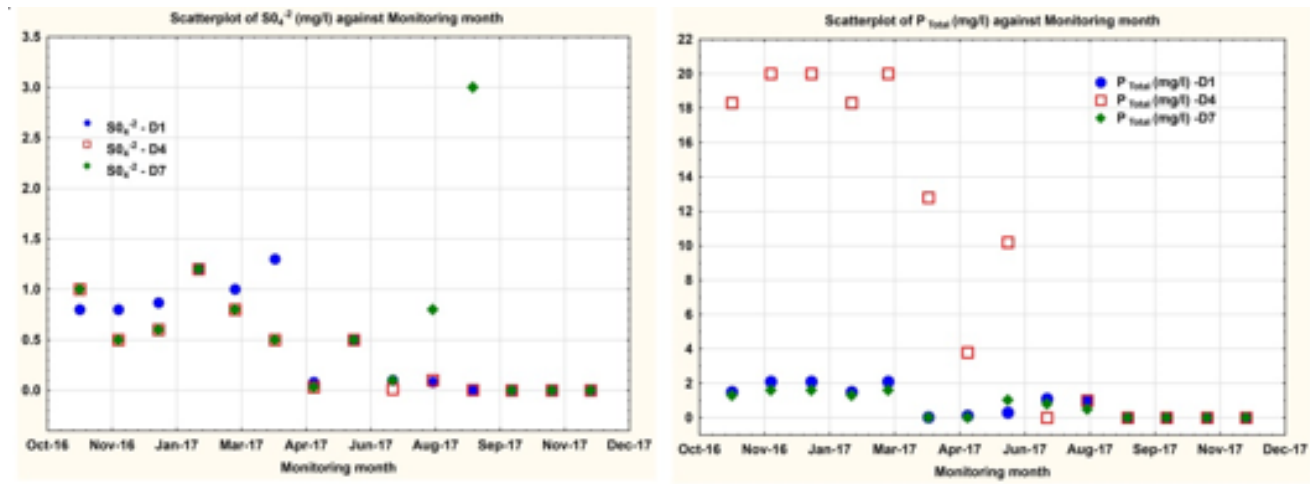

Fig.6. Monthly evolution for $\mathrm{SO}_{4}$ and phosphorus 

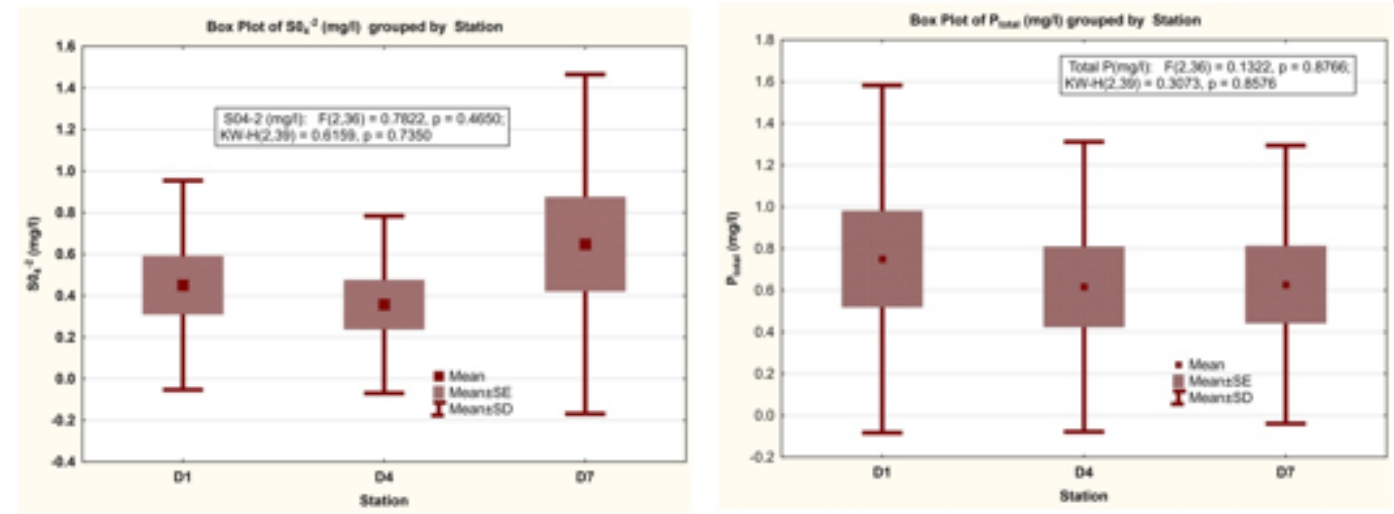

Fig.6a. Box-plot representation to investigate the values recorded in different monitoring points for $\mathrm{SO}_{4}$ and phosphorus

\section{Conclusions}

Based on this investigation, the quality of the water is satisfactory along the Danube's left bank, in the city of Galati area.

Along the $6 \mathrm{~km}$ covered by this study there are no significant variations in physical-chemical parameters for water quality assessment. These results are confirmed by the ANOVA analysis conducted seasonally and annually.

The research will be extended in the neighborhood and will also cover the confluence points with the Siret and Prut rivers to identify the contributions of the tributaries.

Acknowledgements: This work was carried out in the framework of the Ministry of Research and Innovation project -3PS/2.11. 2017 Research to support the development of capacity to assess and mitigate the impact of climate change and other stressors on the state of forest ecosystems and wine-growing yard.

\section{References}

1. *** Water Quality Monitoring - A Practical Guide to the Design and Implementation of Freshwater Quality Studies and Monitoring Programmes, United Nations Environment Programme and the World Health Organization, 1996.

2. *** Medeiros, C., Faial, K. R. F., Faial, K. C. F., Lopes, I.D.S., Lima, M.O., Guimarães, R.M., Mendonca, N.M., Quality index of the surface water of Amazonian rivers in industrial areas in Pará, Brazil, Marine Pollution Bulletin 123, 156-164, (2017).

3. MUSTAFA, M. N., KHALID, A. A., ATHRAA, H.M., ALI, I.A., Assessment of water quality and suitability of Euphrates River in Iraq for drinking purpose by applying water quality indices (WQIS) and geographical information system (GIS) techniques, I.J.S.N., vol.8(4), 741 -756, (2017). 4. DRASOVEAN, R., MURARIU, G., CONDURACHE-BOTA, S., CONSTANTINESCU, G., Studies on the water quality of the Siret river, near Galati city, 18th International Multidisciplinary Scientific Geoconference SGEM 2018, 18(3.1), 687-695, (2018).

5. SALAM, H.E., SALWAN, A.A., Water quality index for Al-Gharraf River, southern Iraq, Egyptian J ournal of Aquatic Research, 43 , 117-122, (2017).

6.ABBASI, T., ABBASI, S.A., Water quality indices, Elsevier, Amsterdam, Netherland, 2012, p. 12.
7. SHWETA, T., BHAVTOSH, S., PRASHANT, S., RAJENDRA, D., Water Quality Assessment in Terms of Water Quality Index, American J ournal of Water Resources, 1(3), 34-38, (2013).

8. YOGENDRA., K., PUTTAIAH, E.T., Determination of Water Quality Index and Suitability of an Urban Waterbody in Shimoga Town, Karnataka, Proceedings of Taal, The 12th World Lake Conference, 342-346, (2008).

9. SING, G., KAMAL, K.A., Application of Water Quality Index for Assessment of Surface Water Quality Status in Goa, Current World Environment, vol. 9(3), 994-1000, (2014).

10. $* * *$ http://www.statisticssolutions.com/correlation-pearsonkendall-spearman/

11. MOCANU, G., A Correlation Analysis on the coordination tests of Physical Education and Sports Faculty's students, from Galati, the Annals of Dunarea de J os University of Galati 2013, Physical Education and Sport Management, 2013, no.2, fascicle XV, ISSN 1434-9832, www.ann.ugal.ro/efms.

12. MOCANU G., Comparative Study on the Development Level of Muscular Strength in the Female Students of the Faculty of Sport and Physical Education (FSPE) and the Faculty of Automatics, Computer Science, Electrical and Electronic Engineering (FACSEEE), the Annals of Dunãrea de Jos University of Galati, 2014, no.2, fascicle XV, p.24, ISSN-L 1434-9832; ISSN 2344-4584, www.ann.ugal.ro/efms.

13. ICONOMESCU T.M., MOCANU G.D.,TALAGHIR L-G., The development of conditional motor skills by means of courses and applicative circuits in 6th grade girls during the Physical Education class, Human. Sport. Medicine / Celovec. Sport. Medicina, vol. 17, no. 4/2017, p.50-57, http:// hsm.susu.ru/hsm/article/view/247, doi (pdf (english)): http://dx.doi.org/10.14529/HSM170406.

14. RUBIA, I., SHAIKH, MD.F., RUHUL, MD.A., FARHA, M.J., MOHAMMOD, J.I., JAHANGIR, MD. A., MOHAMMAD, NAZIR, H., AND MOHAMMAD, A., Assessment of pH and Total Dissolved Substances (TDS) in the Commercially Available Bottled Drinking Water, J ournal of Nursing and Health Science, vol. 6(5), 35-40, (2017).

15. AKTER, T., TUZ JHOHURA, F., AKTER, F., ROY CHOWDHURY, T., MISTRY, S. K., DEY, D., BARUA, MILAN. K., ISLAM, MD. A., AND RAHMAN, M., WATER QUALITY INDEX FOR MEASURING DRINKING WATER QUALITY IN RURAL BANGLADESH: A CROSS-SECTIONAL STUDY, J HEALTH POPUI Nutr., 35(4), (2016), doi: 10.1186/s41043-016-0041-5.

Manuscript received: 21.10 .2018 